Jarostaw Mielcarek

Wyższa Szkoła Bankowa w Poznaniu

\title{
Trzy podstawowe twierdzenia Target Costing o punktach krytycznych
}

\section{THREE BASIC THEOREMS OF TARGET COSTING ABOUT CRITICAL POINTS}

Celem artykułu byto rozwiazanie dwóch problemów: czy dla trzech wyróżnionych punktów krytycznych czyli jednostkowego kosztu dopuszczalnego, nakładów inwestycyjnych dopuszczalnych $i$ dopuszczalnej ceny za najnowszq technologie można sformułować twierdzenia ściśle ogólne, które $w$ poprzedniku okresów warunkowych zawieraja założenia (warunki), dla których $w$ ich nastęniku wskaźniki finansowe osiagaja wielkości oznaczajace uzyskanie sukcesu finansowego w wyniku wdrożenia inwencji, oraz czy jest możliwe zastosowanie trzech podstawowych twierdzeń TC do badania opłacalności przedsięwzięć innowacyjnych, polegajacych na wdrożeniu inwencji $w$ rolnictwie. Takie twierdzenia, petniace role diagnostyczna $i$ wspomagajaca podejmowanie decyzji zostały sformułowane. Rozwiqzano równiez drugi problem $w$ wyniku określenia dla fazy przedprodukcyjnej wdrożenia nowoczesnej szklarni do produkcji pomidorów w ruchu ciagłym, że za pomoca trzech podstawowych twierdzeń TC można sprawdzić, czy spetnione sq warunki osiagnięcia sukcesu finansowego $i$ na tej podstawie podjać poprawna decyzje o wdrożeniu tej inwencji. Głównymi narzędziami badawczymi byty trzy modele strategiczne wdrożenia tej inwencji, które jednocześnie byly dyskontowymi modelami symulacyjnymi. Zastosowano również dodatki Excela Szukaj wyniku i Solver.

Słowa kluczowe: wdrażanie inwencji rolniczej, sukces finansowy, strategiczny model, dyskontowy model symulacyjny, rola diagnostyczna TC, rola wspomagająca podejmowanie decyzji TC,

\section{Wprowadzenie}

W ekonomii, a w szczególności w rachunkowości zarządczej istotne znaczenie ma badanie punktów krytycznych. Definicje punktów krytycznych są definicjami operacyjnymi, czyli podającymi sposób ich wyznaczenia. Najbardziej znanym w ekonomii punktem krytycznym jest punkt progu rentowności (BEP) [Mielcarek, 2005, Żwirbla, 2017 $]^{1}$. Jest on wyznaczony przez wolumen produkcji, dla którego funkcja zysku osiagga wielkość zerową. Można sformułować podstawowe twierdzenie analizy BEP [Mielcarek, 2005, s. 73-74]:

\footnotetext{
${ }^{1}$ Analiza punktów krytycznych jest zagadnieniem szerszym, niż analiza progu rentowności. W analizie progu rentowności chodzi o znalezienie takiego wolumenu produkcji, dla którego następuje zrównanie przychodów z kosztami całkowitymi, czyli zysk osiąga wielkość zerową. W skład analizy punktów krytycznych wchodzą również inne badania, w których poszukuje się takich wielkości parametrów ekonomicznych, dla których są osiągane na minimalnym poziomie inne, niż zysk zmienne zależne.
} 
Jeżeli $v=\frac{K_{s}}{m_{w}}$, to $Z=0$

czyli jeżeli wolumen produkcji (sprzedaży) w przedsiębiorstwie jest równy relacji kosztów stałych do jednostkowej marży wkładu, to zysk w takim przedsiębiorstwie jest zerowy.

Znaczenie analizy punktu krytycznego polega na tym, że jego znajomość umożliwia:

- diagnozę sytuacji przedsiębiorstwa,

- wspomaganie procesu zarządzania,

Próby uratowania Chryslera są dobrym przykładem zastosowania punktu progu rentowności do celów diagnostycznych i wspomagania decyzji zarządczych ${ }^{2}$.

Powstaje pytanie, czy w innych koncepcjach rachunkowości zarządczej, w tym w rachunku kosztów docelowych (Target Costing, w skrócie TC) stosuje się analizę punktów krytycznych i można sformułować podobne twierdzenia, jak w przypadku analizy BEP. Pytanie to ma istotne znaczenie badawcze bowiem jak należy podkreślić, w definicjach TC nie mówi się ani o punktach krytycznych, ani o podstawowych twierdzeniach TC. ${ }^{3}$ Pozytywne rozwiązanie tego problemu rozwinie teorię rachunkowości zarządczej, przyczyni się do wzrostu jej wykorzystania praktycznego i będzie wzmacniać pogląd, że rachunkowość zarządcza jest nauką.

$\mathrm{W}$ artykule będzie podjęty problem badawczy, który zostanie sformułowany następująco za pomocą pytania rozstrzygnięcia: czy dla trzech wyróżnionych punktów krytycznych TC, czyli dla jednostkowego kosztu dopuszczalnego, dopuszczalnych nakładów inwestycyjnych i dopuszczalnej ceny za najnowszą technologię można sformułować twierdzenia na wzór twierdzenia (1) dotyczącego BEP.

Powstaje pytanie, jakiego rodzaju są to twierdzenia. Sa to typowe dla nauki twierdzenia ściśle ogólne, które formułowanie są w postaci okresu warunkowego. W ich poprzedniku wymienione są założenia (warunki), dla których zachodzi to, co jest podane w następniku.

Drugi problem badawczy jest wyrażony za pomocą następującego pytania rozstrzygnięcia: czy jest możliwe zastosowanie trzech podstawowych twierdzeń TC

\footnotetext{
${ }^{2}$ Punkt progu rentowności wynosił w 1978 r. 2,3 mln samochodów rocznie, podczas gdy sprzedaż wynosiła 1 mln samochodów. W istniejących warunkach rynkowych w USA zwiększenie sprzedaży w krótkim okresie o $130 \%$ było niemożliwe. Dlatego powszechnie uważano, że dla tej firmy nie ma ratunku. L. Iacocca, który podjął się w końcu 1978 r. zadania uratowania Chryslera zastosował innowacyjne podejście zarządcze, które polegało na tym, że nie starał się osiągnąć i przekroczyć bieżący punkt progu rentowności (2,3 $\mathrm{mln}$ szt.), lecz obniżyć punkt progu rentowności do bieżących możliwości sprzedaży. W rezultacie uruchomionych działań naprawczych punkt progu rentowności spadł do $1,1 \mathrm{mln}$ samochodów, a firma w $1982 \mathrm{r}$. wyszła ze strefy strat i osiagnęła umiarkowane zyski. W następnym roku zysk wyniósł $925 \mathrm{mln}$ USD, co było najlepszym wynikiem finansowym w historii Chryslera [L. Iacocca, W. Novak: Iacocca. An Autobiography, Bantam Books, New York, s. 293-294].

${ }^{3}$ Omówienie tych definicji jest zamieszczone na przykład w [S. Sojak, H. Jóźwiak: Rachunek kosztów docelowych, Oficyna Ekonomiczna, Kraków 2004, s.57-60; M. Masztalerz: Rachunek kosztów docelowych jako instrument kreowania wartości przedsiębiorstwa, Wydawnictwo Uniwersytetu Ekonomicznego w Poznaniu, Poznań 2011, s. 129-133; Nita, B.: Rachunkowość w zarzadzaniu strategicznym przedsiębiorstwem, Wolters Kluwer Polska Sp. z o.o., Warszawa 2008, s. 270-271]. W związku z brakiem literatury o podstawowych twierdzeniach TC, poza pracami J. Mielcarka w sposób oczywisty w artykule nie ma powołań na dotyczącą tego tematu literaturę.
} 
do badania opłacalności przedsięwzięć innowacyjnych, polegających na wdrożeniu inwencji $\mathrm{w}$ rolnictwie. Rozważania z artykułu, poświęconego wdrożeniu nowoczesnej szklarni zblokowanej do produkcji w ruchu ciaggłym pomidorów [Mielcarek, 2012] zostaną wykorzystane jako przykład.

Celem artykułu jest rozwiązanie podjętych w nim problemów badawczych.

\section{Metody badawcze}

TC służy do analizy opłacalności przedsięwzięć innowacyjnych $\mathrm{w}$ fazie przedprodukcyjnej, gdy jeszcze żadne koszty nie zostały poniesione, czyli jest to analiza ex ante ${ }^{4}$. Przyjęta zostaje $\mathrm{w}$ związku z tym definicja innowacji, że jest to wdrożona inwencja (wynalazek), którą może być nowy lub ulepszony produkt, proces technologiczny, usługa, materiał, surowiec, rynkowa nisza, kanał dystrybucyjny, zmiana organizacyjna lub wdrożenie nowej koncepcji rachunkowości zarządczej, która przyniosła przedsiębiorstwu sukces produkcyjny, rynkowy i finansowy [Mielcarek 2014, s. 213; Mielcarek 2016a, s. 56-57] . Dopiero ex post okazuje się, czy wdrożenie inwencji było słuszne i dlatego działalność innowacyjna jest tak ryzykowna ${ }^{6}$.

$\mathrm{Z}$ definicji innowacji wynikają dwa problemy. Po pierwsze, w jaki sposób poprawnie mierzyć sukces finansowy. Po drugie, w jaki sposób sprawdzić w fazie przedprodukcyjnej, czy dla danej inwencji spełnione są warunki osiagnięcia sukcesu finansowego. Drugi problem jest problemem diagnostycznym, którego rozwiązanie odwołuje się do pojęcia punktów krytycznych w TC.

W modelu dyskontowym TC wybranym jako narzędzie badawcze $\mathrm{z}$ powodu falsyfikacji tradycyjnego modelu TC [Mielcarek, 2016b] można badać trzy najważniejsze punkty krytyczne: jednostkowy koszt dopuszczalny [Mielcarek, 2015], nakłady inwestycyjne dopuszczalne [Mielcarek, 2017] i dopuszczalną cenę za najnowszą technologię [Mielcarek, 2018b]. Słowo dopuszczalny jest tu rozumiane jako maksymalny. Niezbędne jest podanie kryterium określającego, jaka wielkość tych kategorii jest maksymalna, ponieważ nie są to w danych warunkach wielkości maksymalne absolutnie. Dopuszczalna, czyli maksymalna wielkość tych kategorii to taka, dla których jeszcze spełnione są dyskontowe kryteria akceptacji przedsięwzięcia innowacyjnego, czyli NPV jest równe zeru, a IRR stopie dyskontowej.

Narzędziem badawczym, umożliwiającym wyznaczenie dla danego przedsięwzięcia innowacyjnego jednostkowego kosztu dopuszczalnego, dopuszczalnych nakładów inwestycyjnych i dopuszczalnej ceny za najnowszą technologię mogą być formuły analityczne. Jednakże $\mathrm{z}$ tego względu, że stosowanie tych formuł jest w praktyce uciążliwe, użyte zostanie rozwiązanie symulacyjne.

Plan strategiczny, oparty na danych początkowych z artykułu [Mielcarek, 2012] będzie modelem symulacyjnym, za pomocą którego wyznaczone zostaną wartości punktów krytycznych. W porównaniu do artykułu z 2012 r. nastapi w nim zmiana, wynikająca $\mathrm{z}$ tego, że badania nad stosowaniem TC doprowadzily do ustalenia, że minimalna stopa rentowności jest stopą EBITDA (EBITDA jest to zysk operacyjny

\footnotetext{
${ }^{4}$ TC może być również użyte do badania przedsięwzięć inwestycyjnych, nie związanych z wdrażaniem inwencji.

${ }^{5}$ Nowość rozwiązań nie jest warunkiem wystarczającym, aby uznać inwencję za innowację.

${ }^{6} \mathrm{Z}$ definicji tej wynika wniosek, że przedsiębiorstwa wdrażają inwencje (wynalazki), a nie innowacje.
} 
przedsiębiorstwa przed potrąceniem odsetek, podatków i amortyzacji), a planowany koszt jednostkowy jest jednostkowym kosztem własnym sprzedaży bez amortyzacji [Mielcarek, 2015]. W przypadku pozytywnego rozwiązania drugiego problemu badawczego będzie ono potwierdzeniem podstawowych twierdzeń TC.

Wszelkie obliczenia zostaną dokonane za pomocą Excela. Narzędziem, które będzie służyć do przeprowadzania symulacji w przypadku jednostkowego kosztu dopuszczalnego będzie dodatek Szukaj wyniku arkusza kalkulacyjnego Excel. W przypadku dopuszczalnego nakładu inwestycyjnego i dopuszczalnej ceny za najnowszą technologię będzie to dodatek Solver tego arkusza, bowiem poszukiwane będzie rozwiązanie dla dwóch zmiennych, a dodatek Szukaj wyniku ma zastosowanie tylko dla jednej zmiennej.

\section{Trzy podstawowe twierdzenia TC}

Podstawowe twierdzenie TC jest jedynym, precyzyjnym narzędziem badawczym, za pomocą którego określa się, co jest sukcesem finansowym w długim okresie, jak go mierzyć i osiagnąć [Mielcarek 2013, s. 395-396]. Na wątpliwość, czy twierdzenie może być narzędziem badawczym odpowiedzią jest wskazanie, że w modus tollendo tollens przesłanką ogólną jest takie twierdzenie, a jego zakwestionowanie następuje wówczas, gdy $\mathrm{w}$ danym przedsiębiorstwie jest spełniony jego poprzednik, a nie zachodzą jego następstwa [Popper 1977, s. 66-67]. W poprzedniku najważniejszy warunek dotyczy uwzględnianego punktu krytycznego ${ }^{7}$.

\section{Twierdzenie 1 TC dla jednostkowego kosztu dopuszczalnego jako punktu krytycznego}

Jego postać przedstawia się następująco:

Twierdzenie 1. Jeżeli dla planowanego wdrożenia w przedsiębiorstwie inwencji inwestycje są równe inwestycjom planowanym

$$
I=I_{p}
$$

i nakłady na badania i rozwój są równe nakładom planowanym

$$
K_{b}=K_{b p}
$$

i cena jest równa cenie prognozowanej

$$
c=c_{p}
$$

i wolumen sprzedaży jest równy wolumenowi prognozowanemu

$$
V=V_{p}
$$

i wolumen produkcji równa się wolumenowi planowanemu

$$
P=P_{p}
$$

i planowany, jednostkowy koszt własny sprzedaży bez amortyzacji równa się kosztowi dopuszczalnemu

$$
k_{p}=k_{d}=\left(1-R O S_{m}\right) c_{p}
$$

\footnotetext{
${ }^{7}$ Należy jeszcze raz podkreślić, że w modus tollendo tollens $\mathrm{w}$ poprzedniku może jedynie występować $\mathrm{w}$ nauce twierdzenie ogólne, w tym przypadku twierdzenie TC.
} 
to planowana stopa rentowności jest równa minimalnej stopie rentowności

$$
\operatorname{ROS}_{p}=\operatorname{ROS}_{m}
$$

i NPV jest równe zeru

$$
N P V=0
$$

i IRR jest równe stopie dyskontowej

$$
I R R=r
$$

gdzie:

$I_{p}$ - planowane nakłady inwestycyjne, $K_{b p}$ - planowane nakłady na badania i rozwój, $c_{p}$ - prognozowana cena, $V_{p}$ - planowany wolumen sprzedaży, $P_{p}$ - planowany wolumen produkcji, $k_{p}$ - planowany koszt jednostkowy własny sprzedaży bez amortyzacji, $k_{d}{ }^{-}$jednostkowy koszt dopuszczalny, $R O S_{p^{-}}$planowana stopa rentowności mierzona za pomocą EBITDA, $R O S_{m}$ - minimalna stopa rentowności, mierzona za pomocą EBITDA, $N P V$ - wartość bieżąca netto, IRR - wewnętrzna stopa zwrotu, $r$ - stopa dyskontowa.

Warunek (2) jest warunkiem odniesienia sukcesu inwestycyjnego, warunek (3) sukcesu badawczo-rozwojowego, warunek (4) i (5) sukcesu rynkowego, warunek (6) sukcesu produkcyjnego, warunek (7) sukcesu kosztowego. Warunki te łącznie są warunkami osiagnięcia sukcesu finansowego w długim okresie w wyniku zamierzonego wdrożenia inwencji. Ich spełnienie jest niezbędne, aby ex ante był spełnione wskaźnik księgowy (8) i wskaźniki dyskontowe (9) i (10) osiągnięcia sukcesu finansowego. Liczba warunków uzmysławia, jak złożonym zagadnieniem ${ }^{8}$ jest wdrażanie inwencji w istniejących przedsiębiorstwach i start-upach.

Warunki (2) do (7) są wielkościami danymi w planie strategicznym, natomiast niewiadomymi w tym twierdzenie są minimalna stopa rentowności i jednostkowy koszt dopuszczalny. Ich znalezienie nastąpi w następnym punkcie za pomocą symulacji. $Z$ jednostkowym kosztem dopuszczalnym porównywany jest planowany, jednostkowy koszt własny sprzedaży bez amortyzacji.

Zastosowanie diagnostyczne twierdzenia 1 TC $\quad \mathrm{z}$ jednostkowym kosztem dopuszczalnym jako punktem krytycznym dzieli wszystkie przedsięwzięcia innowacyjne na trzy części, co jest jedną z oznak jego uniwersalności [Mielcarek, 2018a] i znamy podzbiór, do którego należy planowana do wdrożenia inwencja. Zarządcze wykorzystanie tego punktu polega na tym, że jednostkowy koszt dopuszczalny dostarcza kryterium decyzyjnego, ponieważ dla dwóch podzbiorów inwencji spełniony jest warunek osiagnięcia sukcesu finansowego. Dla tych podzbiorów planowany, jednostkowy koszt własny sprzedaży bez amortyzacji jest nie większy od jednostkowego kosztu dopuszczalnego. $\mathrm{Z}$ tego względu, że dla podzbioru 3 warunek ten nie jest spełniony należy odrzucić projekt wdrożenia inwencji.

${ }^{8}$ Często nie jest to do końca uświadamiane. 


\section{Twierdzie 2 TC dla dopuszczalnych nakładów inwestycyjnych jako punktu krytycznego}

W modelu TC istnieje poważna luka, która wynika $\mathrm{z}$ przyjęcia jego czterech podstawowych etapów [Cooper, Slagmulder, 1999, s. 23-33]. Nie został uwzględniony etap wyboru wariantu inwestycyjnego na podstawie dopuszczalnych nakładów inwestycyjnych, ani etap wyznaczenia maksymalnej ceny za najnowszą technologię. Nie oznacza to, że uniwersalność czynnościowa TC jest ograniczona [Mielcarek 2018a, s. 84-88], bowiem te wielkości mogą być wyznaczone w ramach dodania brakującego piątego kroku, którego elementami są twierdzenie 2 i 3. Postać pierwszego z tych twierdzeń przedstawia się następująco:

Twierdzenie 2. Jeżeli dla planowanego wdrożenia w przedsiębiorstwie inwencji w poszczególnych latach nakłady inwestycyjne planowane są równe nakładom inwestycyjnym dopuszczalnym

$$
I_{p}=I_{d}
$$

i spełnione są warunki od (3) do (6) z twierdzenia 1

i jednostkowy koszt dopuszczalny równa się jednostkowemu kosztowi własnemu sprzedaży bez amortyzacji

$$
k_{d}=k_{p}
$$

to planowana stopa rentowności jest równa minimalnej stopie rentowności

$$
R O S_{p}=R O S_{m}
$$

i NPV jest równe zeru

$$
N P V=0
$$

i IRR jest równe stopie dyskontowej

$$
I R R=r
$$

$\mathrm{W}$ twierdzeniu $2 \mathrm{w}$ porównaniu $\mathrm{z}$ twierdzeniem 1 zmianie uległ warunek (2) i warunek (7). W twierdzeniu 2 warunek (2) staje się punktem krytycznym. Podaje bowiem maksymalną wielkość nakładów inwestycyjnych, dla których spełnione są jeszcze wskaźniki osiągnięcia sukcesu finansowego, czyli warunki (13), (14) i (15). Dopuszczalne nakłady inwestycyjne są niewiadomą. Ich znalezienie nastapi w następnym punkcie za pomocą symulacji. Jednostkowy koszt dopuszczalny (warunek 7) przestaje być niewiadomą i jest wyznaczony przez jednostkowy koszt własny sprzedaży bez amortyzacji. Oznacza to jednak, że niewiadomą staje się minimalna stopa rentowności, dla której obydwa koszty jednostkowe się zrównują.

Zastosowanie diagnostyczne twierdzenia 2 TC z nakładami inwestycyjnymi dopuszczalnymi jako punktem krytycznym polega na podziale wszystkich przedsięwzięć innowacyjnych na trzy części. Porównanie planowanych nakładów inwestycyjnych z nakładami dopuszczalnymi dostarcza informacji, do którego z tych trzech podzbiorów należy planowana do wdrożenia inwencja. Zarządcze wykorzystanie tego punktu wynika z tego, że nakłady inwestycyjne dopuszczalne dostarczają kryterium decyzyjnego, ponieważ dla dwóch podzbiorów inwencji spełniony jest warunek osiągnięcia sukcesu finansowego, bowiem planowane nakłady inwestycyjne są nie większe od nakładów inwestycyjnych dopuszczalnych. Dla podzbioru 3 warunek ten nie jest spełniony i należy wówczas odrzucić projekt wdrożenia inwencji. 


\section{Twierdzenie 3 TC dla dopuszczalnej ceny za najnowszą technologię jako punktu krytycznego}

Dla tego punktu krytycznego dodany do TC piąty etap będzie polegał na wyznaczeniu ceny maksymalnej za najnowszą technologię.

Postać tego twierdzenia przedstawia się następująco:

Twierdzenie 3. Jeżeli dla planowanego wdrożenia w przedsiębiorstwie inwencji w = poszczególnych latach spełnione są warunki od (2) do (6) z twierdzenia 1

i jednostkowy koszt dopuszczalny jest równy planowanemu, jednostkowemu kosztowi własnemu sprzedaży bez amortyzacji ${ }^{9}$

$$
k_{d}=k_{p}
$$

i cena rynkowa za najnowszą technologię jest równa cenie dopuszczalnej

$$
c_{n}=c_{d}
$$

to planowana stopa rentowności jest równa minimalnej stopie rentowności

$$
R O S_{p}=R O S_{m}
$$

i NPV jest równe zeru

$$
N P V=0
$$

i IRR jest równe stopie dyskontowej

$$
I R R \geq r
$$

gdzie: $c_{n}$ - rynkowa lub wynegocjowana cena za najnowszą technologię, $c_{d}$ - cena dopuszczalna za najnowszą technologię.

W twierdzeniu $3 \mathrm{w}$ porównaniu z twierdzeniem 1 zmianie uległ warunek (7), który teraz ma numer (16) i pojawił się nowy warunek (17). W twierdzeniu 3 warunek (17) staje się punktem krytycznym. Podaje bowiem maksymalną cenę za najnowszą technologię, dla której spełnione są jeszcze wskaźniki osiągnięcia sukcesu finansowego, czyli warunki (18), (19) i (22). Dopuszczalna cena za najnowszą technologię jest niewiadomą. Jej wyznaczenie nastąpi w następnym punkcie za pomocą symulacji.

Zastosowanie diagnostyczne twierdzenia $3 \mathrm{TC}$ z dopuszczalną ceną za najnowszą technologię jako punktem krytycznym w wyniku porównania $\mathrm{z}$ nią ceny rynkowej lub wynegocjowanej za tą technologię dzieli wszystkie przedsięwzięcia innowacyjne na trzy części i znamy podzbiór, do którego należy planowana do wdrożenia inwencja. Zarządcze wykorzystanie tego punktu polega na tym, że cena dopuszczalna dostarcza kryterium decyzyjnego, ponieważ dla dwóch podzbiorów inwencji spełniony jest warunek osiagnięcia sukcesu finansowego, bowiem cena rynkowa (lub wynegocjowana) za najnowszą technologię jest nie większa lub staje się nie większa od ceny dopuszczalnej. Dla podzbioru 3 warunek ten nie jest spełniony i należy wówczas odrzucić projekt wdrożenia najnowszej technologii.

\footnotetext{
${ }^{9}$ To założenie jest takie samo, jak w twierdzeniu 2.
} 


\section{Wyniki badań dotyczące zastosowanie trzech twierdzeń podstawowych do badania opłacalności przedsięwzięcia innowacyjnego $\mathrm{w}$ rolnictwie}

\section{Najważniejsze dane początkowe}

Do określenia planowanego, jednostkowego kosztu własnego sprzedaży bez amortyzacji została zastosowana kalkulacja podziałowa prosta. Dotyczy ona wdrożenia projektu szklarni do produkcji w ruchu ciagłym pomidorów. Planowany, jednostkowy koszt własny sprzedaży bez amortyzacji w zblokowanej szklarni typu Venlo o pow. 1,5 ha wynosi 1,5528 zł dla produkcji uruchomionej w 2004 r. [Rutkowski, 2006, s. 227, Mielcarek, 2012, s. 119-120]. Pozostałe dane początkowe są podane w tabeli 3.

\section{Symulacyjne wyznaczanie jednostkowego kosztu dopuszczalnego}

W modelu symulacyjnym, przedstawionym w tabeli 3 znaleziono minimalną stopę rentowności za pomocą dodatku Szukaj wyniku arkusza kalkulacyjnego Excel. Tak znaleziona stopa rentowności nazywana jest minimalną, ponieważ dla niej dyskontowe kryteria akceptacji przedsięwzięcia inwestycyjnego, czyli NPV i IRR osiagają minimalną, akceptowalną wielkość. Stopa minimalna wynosi $21,37 \%$. Wyniki symulacji zaprezentowane w tabeli 3 potwierdzają twierdzenie 1 .

Tabela 1. Jednostkowy koszt dopuszczalny

\begin{tabular}{|l|r|}
\hline \multicolumn{1}{|c|}{ Wyszczególnienie } & Wielkość \\
\hline Docelowa cena sprzedaży, zł & 3,67 \\
Minimalna stopa rentowności sprzedaży EBITDA, \% & 21,37 \\
Jednostkowy EBITDA, zł & 0,78 \\
Jednostkowy koszt dopuszczalny, zł & 2,89 \\
Planowany, jednostkowy koszt własny sprzedaży bez amortyzacji, zł & 1,5528 \\
\hline
\end{tabular}

Źródło: Opracowanie własne

Dysponując minimalną stopą rentowności określono $\mathrm{w}$ tabeli 1 kolejną niewiadomą, jaką jest jednostkowy koszt dopuszczalny obliczony za pomocą formuły (7). Jest on równy $2,89 \mathrm{zł}$. Istnieje niska wrażliwość warunku osiagnięcia sukcesu finansowego na wzrost jednostkowego kosztu własnego sprzedaży bez amortyzacji. Dopiero wzrost przekraczający $85,8 \%$ doprowadzi do spadku NPV poniżej zera, a IRR poniżej stopy dyskontowej.

Bardzo ważne pytanie dotyczy tego, jak ukształtują się wyniki finansowe, gdy planowany, jednostkowy koszt własny sprzedaży bez amortyzacji jest niższy od jednostkowego kosztu dopuszczalnego, jak to wynika z tabeli 1 oraz gdy spełnione sa pozostałe warunki twierdzenia 1. Wykorzystamy dla udzielenia odpowiedzi model symulacyjny z tabeli 3 i wyniki obliczeń są przedstawione w tabeli 2. 
Tabela 2. Planowany, jednostkowy koszt własny sprzedaży bez amortyzacji niższy od jednostkowego kosztu dopuszczalnego

\begin{tabular}{|l|r|}
\hline \multicolumn{1}{|c|}{ Wyszczególnienie } & \multicolumn{1}{|c|}{ Wielkość } \\
\hline Docelowa cena sprzedaży, zł & 3,67 \\
Koszt jednostkowy własny sprzedaży bez amortyzacji, zł & 1,5528 \\
Jednostkowy koszt dopuszczalny, zł & 2,8857 \\
Jednostkowy EBITDA, zł & 2,1172 \\
Stopa rentowności sprzedaży EBITDA, \% & 57,69 \\
Minimalna stopa rentowności sprzedaży EBITDA, \% & 21,37 \\
NPV, tys. zł & 6808,93 \\
IRR, \% & 38,60 \\
\hline
\end{tabular}

Źródło: Opracowanie własne

Jak wynika $\mathrm{z}$ danych $\mathrm{z}$ tabeli 2 planowana stopa rentowności sprzedaży staje się wówczas wyższa od stopy rentowności minimalnej, NPV staje się większe od zera, a IRR staje się większe od stopy dyskontowej. Wielkości jakie osiagają te wskaźniki finansowe wskazują na wysoką opłacalność przedsięwzięcia innowacyjnego i tym samym niskie ryzyko dla jego wdrożenia.

\section{Symulacyjne wyznaczanie dopuszczalnych nakladów inwestycyjnych}

W modelu symulacyjnym, przedstawionym w tabeli 3 znaleziono dopuszczalne, czyli maksymalne nakłady inwestycyjne, wynoszące 10,1 $\mathrm{mln}$ zł, dla których jeszcze spełnione są kryteria akceptacji przedsięwzięcia inwestycyjnego. Użyto w tym celu dodatku Solver arkusza kalkulacyjnego Excel. W komórce celu podano adres komórki, w której znajduje się wartość całkowitych nakładów inwestycyjnych, w tym na kapitał obrotowy i wybrano opcję, że wartość tę należy maksymalizować. Wielkościami zmienianymi są stopa rentowności sprzedaży i początkowe nakłady inwestycyjne na środki trwałe. Warunkami ograniczającymi są NPV równe zero i jednostkowy koszt dopuszczalny równy planowanemu, jednostkowemu kosztowi własnemu sprzedaży. Wyniki symulacji zaprezentowane w tabeli 4 potwierdzają twierdzenie 2.

Tabela 4. Jednostkowy koszt dopuszczalny dla dopuszczalnych nakładów inwestycyjnych

\begin{tabular}{|l|r|}
\hline \multicolumn{1}{|c|}{ Wyszczególnienie } & Wielkość \\
\hline Docelowa cena sprzedaży, zł & 3,67 \\
Jednostkowy EBITDA, zł & 2,12 \\
Planowany, jednostkowy koszt własny sprzedaży bez amortyzacji, zł & 1,5528 \\
Jednostkowy koszt dopuszczalny, zł & 1,5528 \\
\hline
\end{tabular}

Źródło: Opracowanie własne

Minimalna stopa rentowności wyniosła 57,69\% i dla niej jednostkowy koszt dopuszczalny zrównuje się z planowany, jednostkowym kosztem własnym sprzedaży bez amortyzacji, zgodnie z warunkiem ograniczającym, co podano w tabeli 4 . Należy zauważyć, że znaleziona wielkość nakładów inwestycyjnych jest maksymalna nie tylko w tym sensie, że dla niej spełnione są jeszcze kryteria dyskontowe akceptacji przedsięwzięć inwestycyjnych, lecz także jednostkowy koszt dopuszczalny zrównuje się z jednostkowym kosztem własnym sprzedaży bez amortyzacji, czyli osiąga również maksymalna, akceptowalną wielkość. 
Gdyby planowany nakład inwestycyjny był większy od dopuszczalnego, to NPV spadłoby poniżej zera, IRR obniżyłoby się poniżej stopy dyskontowej, a jednostkowy koszt dopuszczalny stałby się wyższy od jednostkowego kosztu własnego sprzedaży bez amortyzacji. Należałoby wówczas odrzucić taki projekt. Zaistnienie takiego wariantu jest mało prawdopodobne, bowiem analizowane wdrożenie inwencji cechuje niska wrażliwość warunku osiagnnięcia sukcesu finansowego na zmianę nakładów inwestycyjnych. Dopiero ich wzrost przekraczający 306,3\% doprowadzi do spadku NPV poniżej zera, a IRR poniżej stopy dyskontowej.

W tabeli 3 podano, że planowane nakłady inwestycyjne wynoszą $3,3 \mathrm{mln}$ zł, czyli są dużo niższe od dopuszczalnych nakładów inwestycyjnych. Wskazuje to na wysoką rentowność przedsięwzięcia innowacyjnego. W ten sposób ponownie ujawnia się wartość diagnostyczna twierdzenia 2 TC. Jak będą się kształtowały wówczas wskaźniki finansowe przedstawiono $\mathrm{w}$ tabeli 2 . 


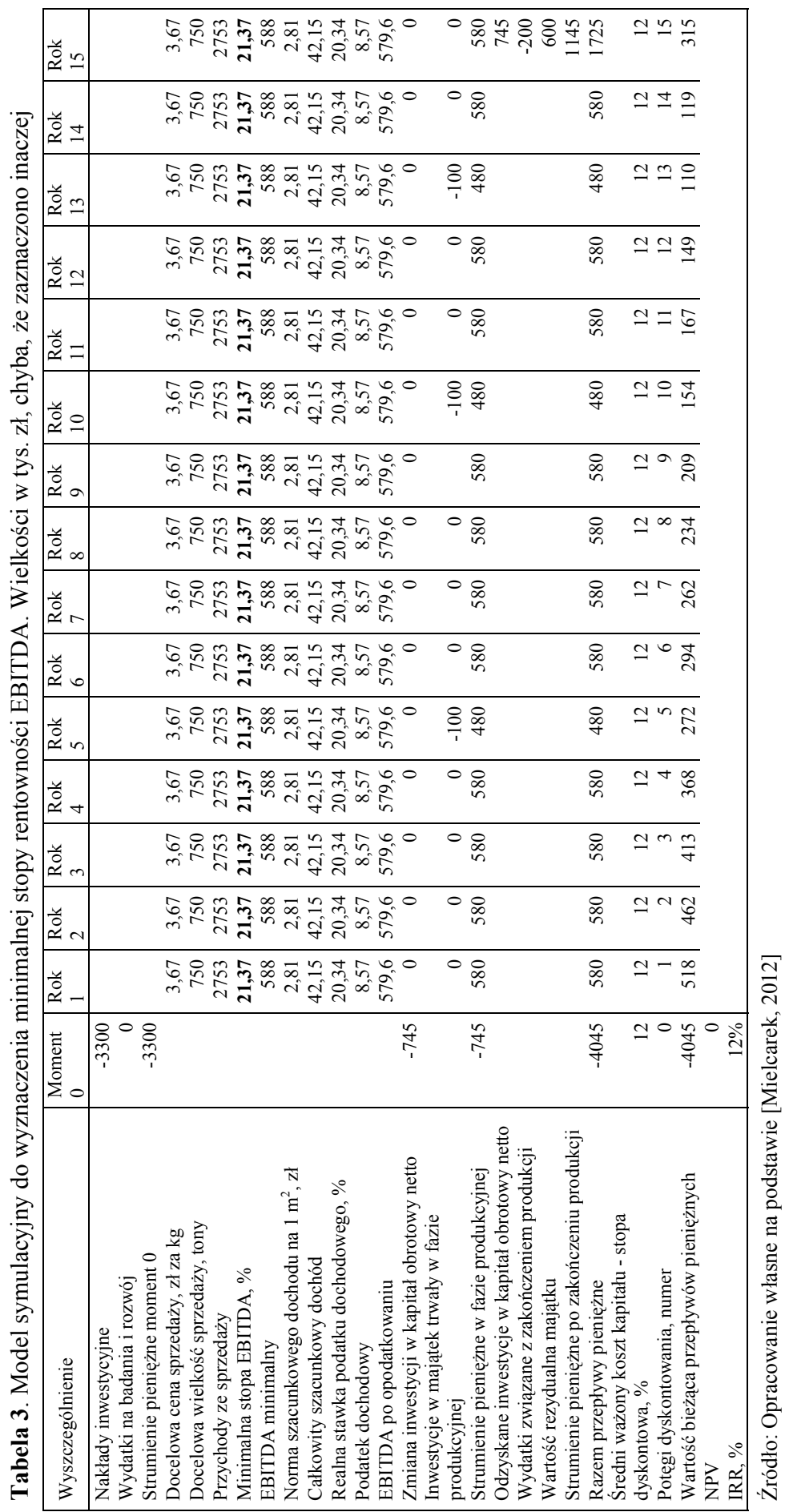




\section{Symulacyjne wyznaczanie dopuszczalnej ceny za najnowszą technologię}

W modelu symulacyjnym, przedstawionym w tabeli 3 znaleziono dopuszczalną, czyli maksymalną cenę za najnowszą technologię, wynoszącą $9,3 \mathrm{mln}$ zł, przy cenie rynkowej wynoszącej $2 \mathrm{mln} \mathrm{z}^{10}$. Istnieje niska wrażliwość warunku osiagnięcia sukcesu finansowego na wzrost ceny rynkowej za najnowszą technologię. Dopiero wzrost przekraczający $367,3 \%$ doprowadzi do spadku NPV poniżej zera, a IRR poniżej stopy dyskontowej.

Najnowsza technologia charakteryzuje się tym, że bez wzrostu nakładów inwestycyjnych następuje wzrost wydajności o ok. $15 \%$ i spadek jednostkowych kosztów o ok. 10\%. Dla dopuszczalnej ceny spełnione są jeszcze kryteria dyskontowe akceptacji przedsięwzięcia innowacyjnego. Dopuszczalna cena została wyznaczona za pomocą dodatku Solver arkusza kalkulacyjnego Excel. W komórce celu podano adres komórki, w której znajduje się wartość całkowitych nakładów inwestycyjnych, na które składają się początkowe nakłady inwestycyjne, w tym na kapitał obrotowy i wydatki na zakup najnowszej technologii. Wybrano opcję, że wartość tę należy maksymalizować. Wielkościami zmienianymi są stopa rentowności sprzedaży i cena za najnowszą technologię. Warunkami ograniczającymi są NPV równe zero i jednostkowy koszt dopuszczalny równy planowanemu, jednostkowemu kosztowi własnemu sprzedaży bez amortyzacji.

Tabela 5. Jednostkowy koszt dopuszczalny dla dopuszczalnej ceny za najnowszą technologię

\begin{tabular}{|l|r|}
\hline \multicolumn{1}{|c|}{ Wyszczególnienie } & Wielkość \\
\hline Docelowa cena sprzedaży, zł & 3,67 \\
Minimalna stopa rentowności sprzedaży EBITDA, \% & 61,92 \\
Jednostkowy EBITDA, zł & 2,2725 \\
Jednostkowy koszt dopuszczalny, zł & 1,3975 \\
Jednostkowy koszt własny sprzedaży bez amortyzacji, zł & 1,3975 \\
\hline
\end{tabular}

Źródło: Opracowanie własne

Minimalna stopa rentowności wyniosła $61,92 \%$ i dla niej jednostkowy koszt dopuszczalny zrównuje się z nowym (niższym) planowanym, jednostkowym kosztem własnym sprzedaży bez amortyzacji, zgodnie $\mathrm{z}$ warunkiem ograniczającym, co podano $\mathrm{w}$ tabeli 5 . Na tej podstawie należy zauważyć, że znaleziona cena za najnowszą technologię jest maksymalna, bowiem dla niej jeszcze spełnione są kryteria dyskontowe akceptacji przedsięwzięci innowacyjnego, lecz także jednostkowy koszt dopuszczalny zrównuje się z jednostkowym kosztem własnym sprzedaży, czyli osiąga również minimalną, akceptowalną wielkość. Planowany, jednostkowy koszt własny sprzedaży bez amortyzacji jest niższy od początkowego, wynoszącego $1,5528 \mathrm{zł}$ z powodu zmiany parametrów dla najnowszej technologii.

\footnotetext{
${ }^{10}$ Zagadnienie ceny maksymalnej za najnowszą technologię współcześnie jest niezwykle aktualne i ważne dla podniesienia poziomu innowacyjności gospodarki polskiej. Często małe i średnie przedsiębiorstwa, które najczęściej nie tworzą najnowszych technologii i stoją wobec decyzji o jej zakupie uważają, że nie stać je na takie technologie. Dopiero zastosowanie TC do rozwiązania tego problemu na podstawie określenia ceny dopuszczalnej i porównania jej z ceną rynkową pozwala podejmować trafne decyzje o jej zakupie.
} 
Cena rynkowa za najnowszą technologię jest niższa od ceny dopuszczalnej i wynosi 2 mln zł. Jakie będą skutki finansowe zakupu najnowszej technologii za taką cenę? Wykorzystując model symulacyjny z tabeli 3 obliczono je i przedstawiono w tabeli 6 .

Tabela 6. Skutki finansowe zakupu najnowszej technologii za cenę niższą od dopuszczalnej

\begin{tabular}{|l|r|}
\hline \multicolumn{1}{|c|}{ Wyszczególnienie } & Wielkość \\
\hline Docelowa cena sprzedaży, zł & 3,67 \\
Jednostkowy koszt własny sprzedaży bez amortyzacji, zł & 1,3975 \\
Jednostkowy koszt dopuszczalny, zł & 2,6476 \\
Jednostkowy EBITDA, zł & 2,2725 \\
Stopa rentowności sprzedaży, \% & 61,92 \\
Minimalna stopa rentowności EBITDA, \% & 27,86 \\
NPV, tys. zł & 7343 \\
IRR, \% & 31,68 \\
\hline
\end{tabular}

Źródło: Opracowanie własne

W tabeli 6 podano, że w rezultacie jednostkowy koszt dopuszczalny stał się wyższy od jednostkowego kosztu własnego bez amortyzacji, NPV stało się większe od zera, a IRR większe od stopy dyskontowej. Spełnione są warunki odniesienia sukcesu finansowego przez firmę, a wielkości tych parametrów wskazują na wysoką opłacalność zakupu najnowszej technologii.

\section{Podsumowanie}

Podjęte w artykule problemy badawcze zostały rozwiązane. Wykazano, że dla trzech wyróżnionych punktów krytycznych TC, czyli jednostkowego kosztu dopuszczalnego, nakładów inwestycyjnych dopuszczalnych i dopuszczalnej ceny za najnowszą technologię można sformułować typowe dla nauki twierdzenia ściśle ogólne, które sformułowane są w postaci okresu warunkowego. W ich poprzedniku wymienione są założenia (warunki), dla których zachodzi to, co jest podane w następniku. Takie twierdzenia pełnią rolę diagnostyczną $i$ wspomagającą podejmowanie decyzji $o$ wdrożeniu inwencji.

Rola diagnostyczna określonych punktów krytycznych polega na podziale wszystkich inwencji na trzy podzbiory pod względem relacji określanej przez uwzględniany punkt krytyczny i twierdzenie TC. Może to być relacja między planowanym, jednostkowym kosztem własnym sprzedaży bez amortyzacji, a jednostkowym kosztem dopuszczalnym, lub między planowanymi nakładami inwestycyjnymi, a nakładami inwestycyjnymi dopuszczalnymi, lub między rynkową (lub umowną) ceną za najnowszą technologię, a dopuszczalną ceną za najnowszą technologię. W pierwszym podzbiorze mamy do czynienia $\mathrm{z}$ relacją nie większy od. $\mathrm{W}$ drugim podzbiorze początkowo nie jest spełniona taka relacja, lecz w wyniku działań organizacyjnych podejmowanych $\mathrm{w}$ fazie przedprodukcyjnej oraz jeżeli jest to potrzebne i możliwe również w fazie produkcyjnej relacja taka zostaje osiągnięta. Trzeci podzbiór charakteryzuje się relacją większy od. W zależności od relacji kształtujących się dla planowanej do wdrożenia inwencji wiemy, do którego $z$ trzech podzbiorów inwencji należy ją zaliczyć.

Wspomagająca funkcja twierdzeń TC przy podejmowaniu decyzji o wdrożeniu inwencji związana jest z tym, że na przykład, jeżeli planowany, jednostkowy koszt 
własny sprzedaży bez amortyzacji jest nie wyższy od jednostkowego kosztu dopuszczalnego, to spełnione są warunki osiagnięcia sukcesu finansowego i można wdrożyć inwencję (dotyczy to podzbioru inwencji jeden i dwa). Jeżeli jednostkowy koszt własny sprzedaży bez amortyzacji jest wyższy od jednostkowego kosztu dopuszczalnego, to nie są spełnione warunki osiagnięcia sukcesu finansowego i należy odrzucić decyzję o wdrożeniu inwencji. Aby twierdzenia TC mogły poprawnie spełniać funkcję diagnostyczną i decyzyjną muszą być również spełnione warunki odniesienia sukcesu inwestycyjnego, badawczo-rozwojowego, rynkowego i produkcyjnego. Liczba tych warunków pokazuje, jak złożonym zagadnieniem jest wdrażanie inwencji w istniejących przedsiębiorstwach i w start-upach oraz wyjaśnia $\mathrm{w}$ znacznym stopniu wysoki współczynnik ich niepowodzeń.

Również w przypadku drugiego problemu, wyrażonego w postaci pytania rozstrzygnięcia: czy jest możliwe zastosowanie trzech podstawowych twierdzeń TC do badania opłacalności przedsięwzięć, polegających na wdrożeniu inwencji w rolnictwie wykazano, że można zastosować je do tego celu. W ten sposób wsparto argument o uniwersalności podmiotowej TC [Mielcarek, 2018, s. 88-89], rozumianej jako dotyczącej wszystkich, którzy prowadzą działalność innowacyjną niezależnie od przynależności sektorowej.

Sprawdzono dla fazy przedprodukcyjnej, czy wdrożenie nowoczesnej szklarni zblokowanej do produkcji w ruchu ciagłym pomidorów spełnia warunki osiagnięcia sukcesu finansowego biorąc pod uwage trzy punkty krytyczne, analizowane w części teoretycznej. Zbudowano trzy modele strategiczne TC, które były dyskontowymi modelami symulacyjnymi dla dopuszczalnego kosztu jednostkowego, dopuszczalnych nakładów inwestycyjnych i dopuszczalnej ceny za najnowszą technologię. Przeprowadzając symulacje posłużono się dodatkami Excela Szukaj wyniku i Solver. Okazało się, że dla wszystkich tych modeli były spełnione warunki odniesienia sukcesu finansowego, bowiem planowany, jednostkowy koszt własny sprzedaży bez amortyzacji był niższy od jednostkowego kosztu dopuszczalnego, planowane nakłady inwestycyjne były niższe od dopuszczalnych nakładów inwestycyjnych, a rynkowa cena za najnowszą technologię była niższa od jej ceny dopuszczalnej. Różnice między wielkościami uwzględnianymi w poszczególnych relacjach są znaczne, co wskazuje na wysoką opłacalność analizowanego przedsięwzięcia. Istnieje niskie ryzyko dla wdrożenia tej inwencji rolniczej, wynikające $\mathrm{z}$ niewielkiej wrażliwości wskaźników finansowych na niekorzystne zmiany parametrów uwzględnionych w modelach strategicznych.

Otrzymane wyniki symulacji potwierdziły trzy podstawowe twierdzenia TC. Zastosowanie praktyczne ustaleń teoretycznych dotyczących punktów krytycznych i podstawowych twierdzeń TC wykazało, że koncepcja ta spełnia funkcje diagnostyczne i zarządcze wobec planowanych do wdrożenia inwencji. Umożliwia zatem podejmowanie poprawnych decyzji w kluczowej współcześnie dziedzinie dla każdego przedsiębiorstwa i całej gospodarki, jaką jest podniesienie poziomu innowacyjności.

\section{Bibliografia}

Cooper R., Slagmulder R.: Develop Profitable New Products with Target Costing, Sloan Management Review 40/1999, s. 23-33.

Iacocca L., Novak W.: Iacocca. An Autobiography, Bantam Books, New York 1989. 
Masztalerz M.: Rachunek kosztów docelowych jako instrument kreowania wartości przedsiębiorstwa, Wydawnictwo Uniwersytetu Ekonomicznego w Poznaniu, Poznań 2011.

Mielcarek J.: Podstawy teoretyczne koncepcji CVP (koszt-wolumen-zysk), Wydawnictwo I-BiS s.c., Wrocław 2005.

Mielcarek J.: Rachunek kosztów docelowych jako narzędzie analizy inwestycji $w$ rolnictwie, w: red. $\mathrm{M}$.

Wasilewski, Ekonomika i organizacja gospodarki żywnościowej, Zeszyty Naukowe SGGW w Warszawie, Wydawnictwo SGGW, Warszawa 97/2012, s. 111-124.

Mielcarek J.: Próba rekonstrukcji podstaw teoretycznych rachunku kosztów docelowych, w: red. E. Nowak, M. Nieplowicz, Systemy rachunku kosztów i kontroli zarządczej, Prace Naukowe Uniwersytetu Ekonomicznego we Wrocławiu, Wydawnictwo UE we Wrocławiu, Wrocław 289/2013, s. 394-405.

Mielcarek J.: Analiza istotnych elementów rachunku kosztów docelowych, w: red. E. Nowak, M. Nieplowicz, Modele zarzadzania kosztami $i$ dokonaniami, Prace Naukowe Uniwersytetu Ekonomicznego we Wrocławiu,

Wydawnictwo Uniwersytetu Ekonomicznego we Wrocławiu, Wrocław 363/2014a, s. 401-416.

Mielcarek J.: Sytuacje rynkowe a innowacja rachunkowości zarzqdczej, w: S. Forlicz red., Wyzwania biznesowe XXI wieku, Zeszyty Naukowe Wyższej Szkoły Bankowej we Wrocławiu, Wydawnictwo WSB w Poznaniu, Wrocław 2014b, s. 211-235.

Mielcarek J.: EBITDA jako podstawa rachunku kosztów docelowych, w: red. E. Nowak, M. Kowalewski, Zarzqdzanie kosztami i dokonaniami, Prace Naukowe Uniwersytetu Ekonomicznego we Wrocławiu,

Wydawnictwo Uniwersytetu Ekonomicznego we Wrocławiu, Wrocław 398/2015, s. 343-353.

Mielcarek J.: On the Need to Continue Diagnosing Low Innovation Performance of the Polish Economy, w: red. J. Mielcarek, Innowacyjność gospodarki, Zeszyty Naukowe Wyższej Szkoły Bankowej w Poznaniu,

Wydawnictwo Wyższej Szkoły Bankowej, Poznań 69(4)/2016a, s. 49-72.

Mielcarek J.: Falsyfikacja tradycyjnego modelu rachunku kosztów docelowych, w: Wyzwania w zarzadzaniu kosztami $i$ dokonaniami, Prace Naukowe Uniwersytetu Ekonomicznego we Wrocławiu, Wydawnictwo UE we Wrocławiu, Wrocław 442/2016b, s. 290-303.

Mielcarek J.: Target Costing a wybór wariantu inwestycyjnego, w: Dylematy zarzadzania kosztami $i$ dokonaniami, Prace Naukowe Uniwersytetu Ekonomicznego we Wrocławiu, Wydawnictwo UE we Wrocławiu, Wrocław 472/2017, s. 236-251.

Mielcarek J.: Ocena uniwersalności Target Costing jako metody zarzadzania innowacjami, w: red. K. Opolski, J. Górski, Innowacyjność polskiej gospodarki: wybrane aspekty, Wydział Nauk Ekonomicznych Uniwersytetu Warszawskiego, Warszawa 2018a, s. 79-92.

Mielcarek, J.: Target Costing a marnotrawstwo (muda) technologiczne, w: Zarzadzanie kosztami i dokonaniami, Prace Naukowe Uniwersytetu Ekonomicznego we Wrocławiu, Wydawnictwo UE we Wrocławiu, Wrocław 514/2018b, s. 272-287.

Nita, B.: Rachunkowość w zarzqdzaniu strategicznym przedsiębiorstwem, Wolters Kluwer Polska Sp. z o.o., Warszawa 2008.

Popper K.R.: Logika odkrycia naukowego, Państwowe Wydawnictwo Naukowe, Warszawa 1977. Rutkowski K.: Energetyczno-ekonomiczne aspekty uprawy pomidora $w$ różnych obiektach szklarniowych, Inżynieria Rolnicza, 2006 nr 6, s. 227.

Sojak S., Jóźwiaka H.: Rachunek kosztów docelowych, Oficyna Ekonomiczna, Kraków 2004.

Żwirbla A.: Nowe podejście do analizy progu rentowności, Wydawnictwo Naukowe PWN, Warszawa 2015. 


\section{Summary}

The aim of the article was to solve two problems: whether for three critical points, i.e. a unit allowable cost, allowable investment outlays and an allowable price for the latest technology, it is possible to formulate strictly general theorems which in the predecessor of conditional periods contain assumptions (conditions) for which in their successor financial ratios reach values, meaning financial success achievement as a result of the implementation of the invention, and whether it is possible to apply the three TC basic theorems to the analysis of the profitability of innovative projects, based on the implementation of inventions in agriculture. Such theorems, performing the diagnostic role and supporting decision-making were formulated. The second problem was also solved for the pre-production phase of the implementation of a modern greenhouse for continuous tomato production, that with three basic TC theorems it is possible to test whether the conditions for achieving financial success are met and, on this basis, make the correct decision to implement this invention. The main research tools were three strategic models of implementation of this invention, which were also discount simulation models. Excel What, if and Solver adds-inn were also applied.

Key Words: agriculture invention implementation, financial success, strategic model, discount simulation model, agriculture invention, TC diagnostic role, TC decision-making role

Informacje o autorze:

dr hab. Jarosław Mielcarek prof. WSB w Poznaniu

Wyższa Szkoła Bankowa w Poznaniu

Poznań,

ul. Powstańców Wlkp. 5,

e-mail: jaroslaw.mielcarek@wsb.poznan.pl

ORCID: 0000-0002-7614-5914. 